\title{
Cross-evaluation of modelled and remotely sensed surface soil moisture with in situ data in southwestern France
}

\author{
C. Albergel $^{1}$, J.-C. Calvet ${ }^{1}$, P. de Rosnay ${ }^{2}$, G. Balsamo ${ }^{2}$, W. Wagner ${ }^{3}$, S. Hasenauer ${ }^{3}$, V. Naeimi ${ }^{3}$, E. Martin ${ }^{1}$, \\ E. Bazile ${ }^{1}$, F. Bouyssel ${ }^{1}$, and J.-F. Mahfouf ${ }^{1}$ \\ ${ }^{1}$ CNRM/GAME (Météo-France, CNRS), URA 1357, Toulouse, France \\ ${ }^{2}$ European Centre for Medium-Range Weather Forecasts, Reading, UK \\ ${ }^{3}$ Institute of Photogrammetry and Remote Sensing, Vienna University of Technology, Vienna, Austria
}

Received: 21 June 2010 - Published in Hydrol. Earth Syst. Sci. Discuss.: 6 July 2010

Revised: 9 October 2010 - Accepted: 25 October 2010 - Published: 3 November 2010

\begin{abstract}
The SMOSMANIA soil moisture network in Southwestern France is used to evaluate modelled and remotely sensed soil moisture products. The surface soil moisture (SSM) measured in situ at $5 \mathrm{~cm}$ permits to evaluate SSM from the SIM operational hydrometeorological model of Météo-France and to perform a cross-evaluation of the normalised SSM estimates derived from coarse-resolution $(25 \mathrm{~km})$ active microwave observations from the ASCAT scatterometer instrument (C-band, onboard METOP), issued by EUMETSAT and resampled to the Discrete Global Grid (DGG, $12.5 \mathrm{~km}$ gridspacing) by TU-Wien (Vienna University of Technology) over a two year period (2007-2008). A downscaled ASCAT product at one kilometre scale is evaluated as well, together with operational soil moisture products of two meteorological services, namely the ALADIN numerical weather prediction model (NWP) and the Integrated Forecasting System (IFS) analysis of Météo-France and ECMWF, respectively. In addition to the operational SSM analysis of ECMWF, a second analysis using a simplified extended Kalman filter and assimilating the ASCAT SSM estimates is tested. The ECMWF SSM estimates correlate better with the in situ observations than the MétéoFrance products. This may be due to the higher ability of the multi-layer land surface model used at ECMWF to represent the soil moisture profile. However, the SSM derived from SIM corresponds to a thin soil surface layer and presents good correlations with ASCAT SSM estimates for the very first centimetres of soil. At ECMWF, the use of a new data assimilation technique, which is able to use the ASCAT SSM, improves the SSM and the root-zone soil moisture analyses.
\end{abstract}

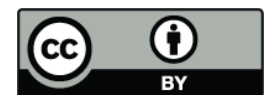

Correspondence to: J.-C. Calvet (calvet@meteo.fr)

\section{Introduction}

The SMOSMANIA (Soil Moisture Observing System - Meteorological Automatic Network Integrated Application) network is a long-term data acquisition effort of profile soil moisture observations in Southwestern France (Calvet et al., 2007; Albergel et al., 2008). With this project, soil moisture profile measurements at 12 automated weather stations of Météo-France from the RADOME (Réseau d'Acquisition de Données d'Observations Météorologiques Etendu) network, have been obtained since January 2007. The main objective of SMOSMANIA is to assess remotely sensed and modelled soil moisture products. Soil moisture is a key variable for land surface monitoring as it controls hydrological processes (runoff, evaporation from bare soil and transpiration from the vegetation cover) and impacts plant growth and carbon fluxes. As a consequence, a significant amount of studies have been and are currently conducted to obtain soil moisture estimates. For that purpose, land surface modelling (Dirmeyer et al., 1999; Georgakakos and Carpenter, 2006 among others) and remote sensing techniques (Wagner et al., 1999, 2007a; Kerr et al., 2001, 2007; Njoku et al., 2003) are used. In situ soil moisture observations are needed to evaluate soil moisture products derived from either modelling or remote sensing.

At Météo-France, modelled surface soil moisture (SSM) data are obtained through the SIM (SAFRAN, ISBA, MODCOU) suite of models. The SIM system is a combination of three components: (i) the SAFRAN (Durand et al., 1993) atmospheric analysis provides the atmospheric forcing, (ii) the ISBA (Noilhan and Planton, 1989; Noilhan and Mahfouf, 1996) land surface model (LSM) computes the surface water and energy budgets, and (iii) the MODCOU (Ledoux et al., 1989) hydrological model simulates the river flow. SIM was validated for several large-scale catchments in Europe

Published by Copernicus Publications on behalf of the European Geosciences Union. 
(Habets et al., 1999; Etchevers et al., 2001; Voirin-Morel, 2003; Artinyan et al., 2008 among others), and implemented over the whole metropolitan France in 2002. SIM has been used operationally at Météo-France since 2003 to monitor the water resource in near real time (Habets et al., 2008) at a national scale (with a $8 \times 8 \mathrm{~km}$ resolution).

Spaceborne microwave instruments are able to provide quantitative information about the water content of a shallow near surface layer (Schmugge, 1983), particularly in the low-frequency microwave region from 1 to $10 \mathrm{GHz}$. Whereas it was shown that surface soil moisture influences the microwave emission of vegetated surfaces from L-band to Kband ( 1.42-23.8 GHz, Calvet et al., 2010), L-band is the optimal wavelength range to observe soil moisture. Apart from a few days of L-band radiometric observations on Skylab between June 1973 and January 1974 (Jackson et al., 2004) current or past instruments have been operating at frequencies above $5 \mathrm{GHz}$. The Soil Moisture and Ocean Salinity mission (SMOS), is a dedicated soil moisture mission launched in November 2009 (Kerr et al., 2001, 2007). It consists of a spaceborne L-band $(\sim 1.42 \mathrm{GHz}, 21 \mathrm{~cm})$ interferometric radiometer able to provide global SSM estimates at a spatial resolution of about $40 \mathrm{~km}$, with a sampling time of 2-3d. Another sensor, the Advanced Scatterometer ASCAT onboard METOP (launched 2006) also produces SSM estimates with a spatial resolution of $50 \mathrm{~km}$ and $25 \mathrm{~km}$ (resampled to $25 \mathrm{~km}$ and $12.5 \mathrm{~km}$ grids in the swath geometry). ASCAT is a radar operating at $5.255 \mathrm{GHz}$ (Wagner et al, 2007b; Bartalis et al., 2007a, b; Albergel et al., 2009).

The verification of the SSM products is not easy, as longterm and large-scale SSM observation networks are sparse. Therefore, it is of interest to conceive new validation methods, complementing the existing soil moisture networks (Wagner et al., 2007b). Land surface models can be used to upscale the in situ SSM observations and complete the evaluation of satellite products, assuming that models, forced with high quality atmospheric forcing data, adequately capture the SSM temporal dynamic. In a previous study, Rüdiger et al. (2009) presented an inter-comparison of remotely sensed (ERS-Scat, Wagner et al., 1999a; AMSR-E, Njoku et al., 2003), observed and modelled SSM over France. For that purpose, the SIM model was used. Their work was motivated by the need to validate remotely sensed products, in particular the representation of the seasonal and interannual variability. They considered a period of three years (2003-2005). They assumed that SSM simulations over France from SIM may be used as credible estimates for the evaluation of remotely sensed SSM. However, they could evaluate the SIM model over one site in Southwestern France only, namely the SMOSREX experimental site (de Rosnay et al., 2006).

Operational soil moisture products are also available from numerical weather prediction (NWP) services such as Météo-France and ECMWF (European Centre for MediumRange Weather Forecasts), among others. Currently, the soil moisture analysis systems used for NWP applications are based on observed screen-level variables, namely air temperature and relative humidity at two meters above the ground, $T_{2 \mathrm{~m}}$ and $\mathrm{RH}_{2 \mathrm{~m}}$, respectively (Drusch et al., 2009; de Rosnay et al., 2009). Simple assimilation techniques were developed for that purpose, such as Optimal Interpolation (OI) (Mahfouf et al., 1991). This technique is used operationally at Météo-France (Giard and Bazile, 2000), ECMWF (Douville et al., 2000) and at the Canadian Meteorological Centre (Bélair et al., 2003). However several studies have showed that while this method improves the forecast skill for surface atmospheric variables, it may not improve the modelled soil moisture content (Drusch and Viterbo, 2007; van den Hurk et al., 2008). Therefore, observations having a more direct link with soil variables than $T_{2 \mathrm{~m}}$ and $\mathrm{RH}_{2 \mathrm{~m}}$ are required. New spaceborne observation techniques are able to provide such variables like soil moisture estimates at a global scale. As the Optimal Interpolation (OI) technique developed by Mahfouf (1991) is not flexible enough to easily account for new observation types (Mahfouf et al., 2009), the operational analysis systems need to be modified to make optimal use of satellitebased land surface information. Hence, at ECMWF (Drusch et al., 2009) and Météo-France (Mahfouf et al., 2009), new Extended Kalman Filter (EKF) analysis systems are under development, which are able to assimilate $T_{2} \mathrm{~m}$ and $\mathrm{RH}_{2} \mathrm{~m}$ together with soil moisture estimates from remote sensing.

In this study, the operational soil moisture product from ECMWF (from the Integrated Forecasting System, IFS, with the $\mathrm{OI}$ analysis based on $T_{2} \mathrm{~m}$ and $\mathrm{RH}_{2 \mathrm{~m}}$ ) and Météo-France (from ALADIN, Aire Limitée Adaptation Dynamique et développement InterNational, with the OI analysis based on $T_{2 \mathrm{~m}}$ and $\mathrm{RH}_{2 \mathrm{~m}}$ ) are evaluated thanks to in situ measurements. Furthermore, another soil moisture product from ECMWF is also evaluated, which uses a simplified EKF for soil moisture analysis (Drusch et al., 2009) to assimilate ASCAT SSM estimates, in addition to $T_{2 \mathrm{~m}}$ and $\mathrm{RH}_{2 \mathrm{~m}}$.

This study presents a cross-evaluation of in situ, remotely sensed and simulated SSM estimates, in Southwestern France. After a description of the different SSM data sets used in this study, the SIM estimates of SSM are evaluated over a two-year period (2007-2008) using the in situ SSM observations of the twelve stations of the SMOSMANIA network and of the SMOSREX experimental site. Then the ASCAT SSM estimates are compared with the in situ and SIM SSM estimates. A downscaling method is applied to the ASCAT SSM in order to obtain a one-kilometre scale product and the added value of this new data set is assessed through the spatial correlation with the SMOSMANIA network. Finally, an evaluation of the NWP SSM of ECMWF and Météo-France is presented. The different soil moisture data sets used in this study are presented in Table 1. 

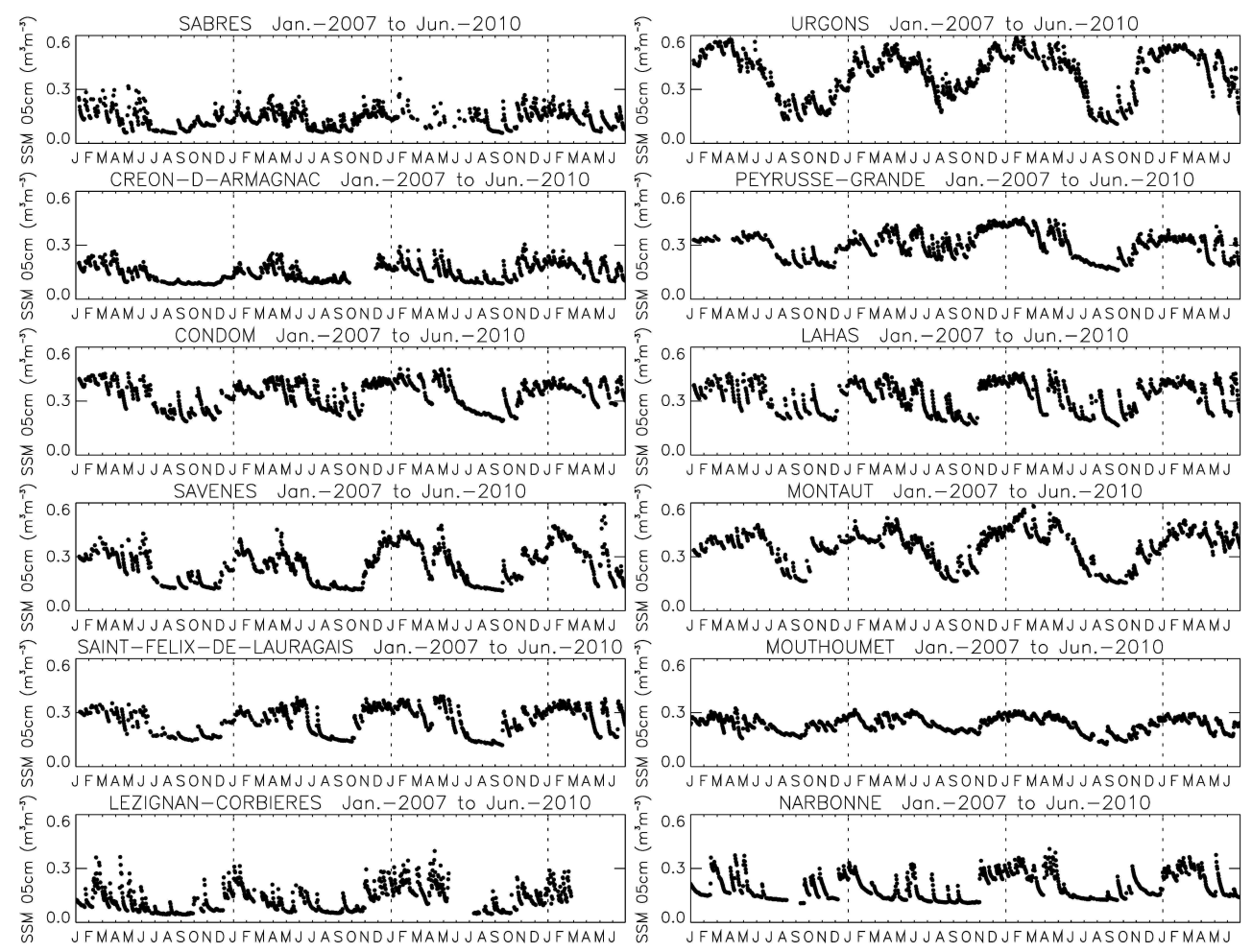

Fig. 1. Daily average $5 \mathrm{~cm}(\mathrm{SSM})$ volumetric soil moisture content $\left(\mathrm{m}^{3} \mathrm{~m}^{-3}\right)$ for the twelve stations of the SMOSMANIA network over a two year and six month period (January 2007-June 2009).

\section{Material and methods}

\subsection{In situ soil moisture observations}

\subsubsection{The SMOSMANIA network}

The SMOSMANIA soil moisture network has several objectives including: (i) the validation of the operational soil moisture products of Météo-France, produced by the hydrometeorological SIM model (Habets et al., 2005, 2008), (ii) the validation of new versions of the ISBA land surface model of Météo-France, (iii) ground-truthing of airborne $\mathrm{Cal} / \mathrm{Val}$ campaigns in support of the SMOS mission and (iv) the evaluation of remotely sensed soil moisture products. Twelve stations of the existing automatic weather station network of Météo-France (RADOME) in Southwestern France were equipped with soil moisture probes at four depths $(5,10,20$ and $30 \mathrm{~cm}$ ). The RADOME stations observe air temperature and relative humidity, wind speed and precipitation. Downwelling shortwave radiation is also measured at some stations. The twelve stations of the SMOSMANIA network are located along a $400 \mathrm{~km}$ transect between the Mediterranean Sea and the Atlantic Ocean following the climatic gradient between the two coastlines. The soil moisture measurements are in units of $\mathrm{m}^{3} \mathrm{~m}^{-3}$, they are derived from capacitance probes: ThetaProbe ML2X of Delta-T Devices, easily inter- faced with the RADOME stations. A ThetaProbe provides a signal in units of volt and its variations is virtually proportional to changes in the soil moisture content over a large dynamic range (White et al., 1994). In this study, in order to convert the voltage signal into a volumetric soil moisture content, site-specific calibration curves were developed using in situ gravimetric soil samples, for each station, and each depth i.e., 48 calibrations curves (Calvet et al., 2007; Albergel et al., 2008). The ThetaProbes were installed in 2006 and have produced continuous observations since then, with a sampling time of $12 \mathrm{~min}$. In this study, data acquired from January 2007 to June 2009 are used. Along with soil moisture measurements, soil temperature is also measured. Figure 1 shows the daily average $5 \mathrm{~cm}(\mathrm{SSM})$ volumetric soil moisture content for the twelve stations over a 30-month period (January 2007 to June 2009).

While SMOSMANIA was designed to support the validation of soil moisture estimates from SMOS, other satellitederived SSM products may be considered, together with model soil moisture estimates over France (Rüdiger et al., 2009; Albergel et al., 2008), e.g. AMSR-E (Advanced Microwave Scanning Radiometer for Earth Observing System), WindSAT (a multi-frequency polarimetric microwave radiometer), or ASCAT. 
Table 1. Presentation of the different soil moisture products used in this study. NWP and LSM stand for numerical weather prediction, and land surface model, respectively.

\begin{tabular}{|c|c|c|c|c|}
\hline Soil moisture data set & Type & Soil layer depth & Considered period & Spatial resolution \\
\hline SMOSMANIA & In situ observation & $5 \mathrm{~cm}$ & $\begin{array}{l}\text { January } 2007 \text { to } \\
\text { December } 2008 \text {; } \\
\text { July } 2008 \text { to } \\
\text { June } 2009\end{array}$ & Local scale \\
\hline SMOSREX & In situ observation & $0-6 \mathrm{~cm}$ & $\begin{array}{l}\text { January } 2007 \text { to } \\
\text { December } 2008\end{array}$ & Local scale \\
\hline SIM & $\begin{array}{l}\text { Hydro- } \\
\text { meteorological } \\
\text { model }\end{array}$ & $\begin{array}{l}\text { Thin surface layer } \\
\text { (ISBA LSM) }\end{array}$ & $\begin{array}{l}\text { January } 2007 \text { to } \\
\text { December } 2008 \text {; } \\
\text { July } 2008 \text { to } \\
\text { June } 2009\end{array}$ & $8 \mathrm{~km}$ \\
\hline ASCAT & $\begin{array}{l}\text { Remotely sensed } \\
\text { (Active radar at C } \\
\text { band } 5.255 \mathrm{GHz} \text { ) }\end{array}$ & $0.5-2 \mathrm{~cm}$ & $\begin{array}{l}\text { January } 2007 \\
\text { to December } 2008\end{array}$ & $\begin{array}{l}25 \mathrm{~km} \text { resampled } \\
\text { to a Discrete Global } \\
\text { Grid: DGG, } 12.5 \mathrm{~km} \\
\text { grid spacing }\end{array}$ \\
\hline ALADIN & $\begin{array}{l}\text { NWP model (using } \\
\text { the ISBA LSM) }\end{array}$ & Thin surface layer & $\begin{array}{l}\text { July } 2008 \text { to } \\
\text { June } 2009\end{array}$ & $9.5 \mathrm{~km}$ \\
\hline $\begin{array}{l}\text { IFS ECMWF } \\
\text { (using the } \\
\text { HTESSEL LSM) }\end{array}$ & NWP model & $\begin{array}{l}0-7 \mathrm{~cm} \text { and } \\
7-28 \mathrm{~cm}\end{array}$ & $\begin{array}{l}\text { July } 2008 \text { to } \\
\text { June } 2009\end{array}$ & 23 km (T799) \\
\hline $\begin{array}{l}\text { IFS_f6ui (using } \\
\text { the HTESSEL LSM) }\end{array}$ & NWP model & $\begin{array}{l}0-7 \mathrm{~cm} \text { and } \\
7-28 \mathrm{~cm}\end{array}$ & $\begin{array}{l}\text { July } 2008 \text { to } \\
\text { June } 2009\end{array}$ & 23 km (T799) \\
\hline
\end{tabular}

\subsubsection{The SMOSREX experimental site}

Located along the SMOSMANIA transect, the SMOSREX experimental site (de Rosnay et al., 2006) is also used in this study as it includes profile soil moisture observations since 2001. SSM measurements are performed with a vertically installed ThetaProbe $(0-6 \mathrm{~cm})$ and every ten centimetres until almost one meter depth $(10,20,30,40,50,60,70,80$ and $90 \mathrm{~cm}$ ). Additionally to those measurements, all the atmospheric forcing data required to run a LSM such as ISBA are observed, as well as energy and carbon fluxes. An L-Band radiometer (Lemaitre et al., 2004) placed $15 \mathrm{~m}$ above the soil observes the L-band brightness temperature of the grassland. It was found that water, energy and carbon fluxes measured at SMOSREX correlate well with simulations of the $\mathrm{CO}_{2}$ responsive version of ISBA, ISBA-A-gs (Albergel et al., 2010).

Figure 2 presents the 12 stations of the SMOSMANIA network and the SMOSREX experimental site in south-western France. Most stations are located in relative flat areas.

\subsection{ASCAT soil moisture estimates}

The Advanced SCATterometer ASCAT onboard METOP (launched in 2006) is, like ERS-1\&2, a real aperture radar instrument measuring radar backscatter with a good accuracy

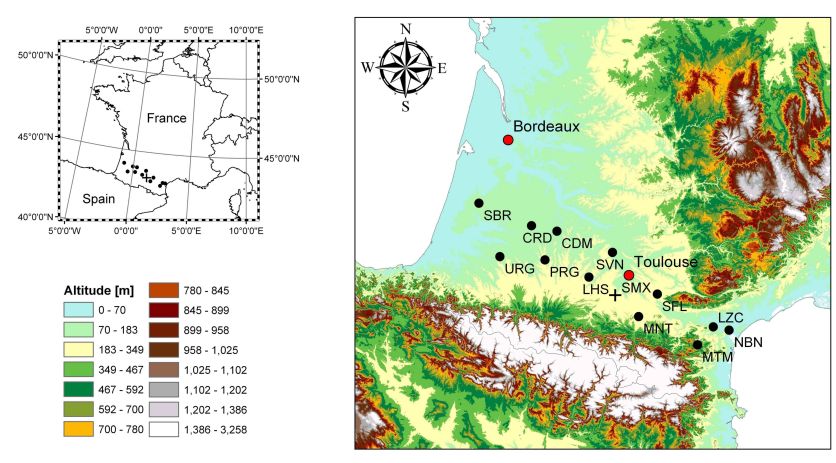

Fig. 2. SMOSMANIA stations in southwestern France (black dots), forming a $400 \mathrm{~km}$ transect between the Atlantic Ocean and the Mediterranean sea. The + symbol is for the SMOSREX site.

and stability (Bartalis et al., 2007b). ASCAT uses a VV polarization in the C-band at about $5.255 \mathrm{GHz}$ and observes the Earth surface with a spatial resolution of $50 \mathrm{~km}$ and $25 \mathrm{~km}$. Similar to the predecessors ERS-1\&2, three antenna beams measure the radar backscatter at each sampling node, but at two sub-swaths with nearly $500 \mathrm{~km}$ in total width. The result is three independent backscatter measurements at the nodes of a $25 \mathrm{~km}$ orbit grid at different viewing angles and 
separated by a short time delay (Attema, 1991). Land cover and vegetation phenology affect the spatial and temporal behaviour of the scatterometer. Wagner et al. (1999b) demonstrated that using a time series-based approach could minimize the influence of the vegetation for soil moisture retrieval. They proposed to scale the backscatter coefficient, extrapolated to a reference incidence angle of $40^{\circ}$, between the lowest and highest values measured over a 15 -yr long period. In this study, the change-detection model parameters used for retrieving SSM from ASCAT backscatter observations are ERS-derived parameters. A new ASCAT data set is now available and parameters used for SSM retrieval are fully ASCAT-derived parameters (Brocca et al., 2010b). However, as the former is considered in the ECMWF algorithm, all the results presented in this study are based on the ERS-based ASCAT product.

In a previous study, Albergel et al. (2009) found an estimate of the average error of ASCAT SSM retrieval of $0.06 \mathrm{~m}^{3} \mathrm{~m}^{-3}$ when comparing ASCAT estimates to in situ SSM observations at 11 stations of the SMOSMANIA network over a 6-month period (April to September 2007). This value is consistent with the estimate given by Pellarin et al. (2006) for ERS-Scat, over a region in Southwestern France. While Albergel et al. (2009) used orbit data delivered by EUMETSAT, the ASCAT data used in this study (also issued by EUMETSAT) were resampled to the Discrete Global Grid (DGG, $12.5 \mathrm{~km}$ grid spacing) by TU-Wien (Institute of Photogrammetry and Remote Sensing, Vienna University of Technology) over a two year period, 2007-2008, generated by their new processor (WAter Retrieval Package, WARP-5, Naeimi et al., 2009). This re-sampling was done in order to get time series and to facilitate the comparison with single point soil moisture products. Albergel et al. (2009) confirmed that along the SMOSMANIA transect, soil moisture measured at a specific location is correlated with the mean soil moisture content derived from the very low resolution ASCAT data. Indeed, several studies have shown that soil moisture variations in space and time can be related to small scale and large-scale components (Entin et al., 2000). The large-scale component is related to the atmospheric forcing (precipitation and evaporation processes) and the small-scale component is mainly due to soil properties, land cover attributes and local topography. The temporal stability concept proposed by Vachaud et al. (1985) indicates that soil moisture patterns tend to persist in time and therefore that soil moisture observed at a single point is often highly correlated with the mean soil moisture content over an area. To some extent, it is possible to estimate soil moisture over an area from local measurements. Conversely, Wagner et al. (2008) showed that downscaling very low resolution SSM using remote sensing techniques is possible. The ASAR (Advanced Synthetic Aperture Radar) spaceborne instrument onboard ENVISAT provides measurements sensitive to soil moisture at a kilometre scale every ten days, and one can assume that the temporally stable soil moisture patterns are reflected in the radar backscatter measurements. It represents the local scale, mostly driven by local conditions (see above) whereas ASCAT data represents the large scale, driven by the atmospheric forcing.

\subsection{Soil moisture products from land surface models}

\subsubsection{SIM}

In this study, the SIM model suite SAFRAN-ISBAMODCOU provides a SSM data set, from January 2007 to December 2008. SAFRAN (Système d'analyse fournissant des renseignements atmosphériques à la neige, Durand et al., 1993) is a mesoscale atmospheric analysis system providing gridded surface meteorological variables. It was initially developed to provide an analysis of the atmospheric forcing in French mountainous areas for avalanche forecasting. SAFRAN analyses eight parameters: $10-\mathrm{m}$ wind speed, 2-m relative humidity, 2-m air temperature, cloudiness, incoming solar and atmospheric radiations, snowfall and rainfall. Hence, it provides an analysis for the main atmospheric forcing parameters using information from more than 1000 meteorological stations and more than 3500 daily rain gauges throughout France. For each variable analysed, an optimal interpolation method is used to assign values to given altitudes within the zone. A detailed description of the SAFRAN analysis over France is presented in QuintanaSegui et al. (2008). They also show that a good correlation between the SAFRAN database and in situ observations exists. The land surface scheme used in SIM is ISBA. It is the land surface model used in the NWP, research and climate models of Mété-France. In the ISBA version used in this study, the soil hydrology is based on the force restore approach. The soil is represented by one bulk reservoir corresponding to the maximum rooting depth, including a thin surface layer, and regardless of the actual root development, according to Deardorff (1978). In the SIM system, the soil layer and soil moisture dynamics are modelled within a three soil-layer model (Boone et al., 1999), together with the explicit multilayer snow model (Boone and Etchevers, 2001). The soil and vegetation parameters used by ISBA are derived from a global database of soils and ecosystems, the ECOCLIMAP database (Masson et al., 2003). In SIM, the ISBA parameters, provided at a resolution of $1 \mathrm{~km}$ by ECOCLIMAP, are aggregated at the spatial resolution of the model, i.e. $8 \mathrm{~km}$.

MODCOU is a hydrogeological model that computes the spatial and temporal evolution of the piezometric level of multilayer aquifers (Ledoux et al., 1989). However it was not used in the current study.

\subsubsection{ALADIN}

The ISBA land surface model parameterization is used in the French NWP models - the global variable resolution 
model ARPEGE (Action de Recherche Petite Echelle Grande Echelle) and the embedded limited area model ALADIN (Aire Limitée Adaptation Dynamique Développement International). ALADIN is a spectral limited area model with a spatial resolution of $9.5 \mathrm{~km}$, using a 6-h window 3-D-Var assimilation system (forecast range: $54 \mathrm{~h}$ ). The surface analysis is independent from the 3-D-VAR atmospheric analysis (Fischer et al., 2006). Observations of $T_{2 \mathrm{~m}}$ and $\mathrm{RH}_{2 \mathrm{~m}}$ are used to analyse soil temperature and soil moisture following Mahfouf (1991) and using the OI coefficients determined by Giard and Bazile (2000) for the ISBA model. Before February 2009, the ALADIN analysis consisted of a simple interpolation of the global ARPEGE analysis to the ALADIN grid.

\subsubsection{IFS}

The IFS cycles used in operations at ECMWF in 2009 are $35 \mathrm{r} 1,35 \mathrm{r} 2$ and $35 \mathrm{r} 3$. In these cycles the soil moisture analysis is based on observed screen-level parameters $\left(T_{2} \mathrm{~m}\right.$ and $\mathrm{RH}_{2} \mathrm{~m}$ ) and the assimilation technique used is the optimal interpolation as described at http://www.ecmwf.int/research/ ifsdocs/CY33r1/. Within the ECMWF's IFS, an advanced surface data assimilation system has also been developed and is under implementation in operations, in order to optimally combine conventional observations with satellite measurements. It is based on a Simplified Extended Kalman Filter (SEKF). The SEKF is described in Drusch et al. (2009) and its implementation and evaluation are described in de Rosnay et al. (2009). The IFS land surface model is H-TESSEL, a multilayer model considering four soil layers $(0-7,7-28$, 28-100, 100-289 cm) (Balsamo et al., 2009). The operational IFS soil moisture analysis is produced daily at 00:00, 06:00, 12:00 and 18:00 UTC, at a spatial resolution of $23 \mathrm{~km}$ (T799). As for ALADIN, the surface analysis is independent from the 4-D-VAR atmospheric analysis. In this study, the 00:00 UTC analysis is considered. The operational SSM product (OI, $T_{2 \mathrm{~m}}$ and $\mathrm{RH}_{2} \mathrm{~m}$ ) is evaluated together with the IFS F6ui research product based on the SEKF assimilation of $T_{2 \mathrm{~m}}, \mathrm{RH}_{2 \mathrm{~m}}$ ) and ASCAT SSM observations. It is not the first attempt to use satellite derived soil moisture at ECMWF. In a previous study, Scipal et al. (2008) examined the potential of ASCAT SSM based on data from its predecessor instruments, the ERS-1\&2. They used a nudging scheme to assimilate those data and found an increase in correlations and a decrease in RMSE when comparing the resulting soil moisture to in situ data of the Oklahoma Mesonet.

\subsection{Data preparation}

ASCAT SSM estimates represent a relative measure of the soil moisture content in the first few centimetres of the soil which are sensed by C-band microwaves, about 0.5 to $2 \mathrm{~cm}$ according to Schmugge (1983). Those data correspond to the degree of saturation of the topmost soil layer and are given in units of percent, ranging between 0 (dry) to 100 (wet). The ASCAT SSM data were rescaled following the approach presented by Rüdiger et al. (2009). The $90 \%$ confidence interval was chosen to define the upper and lower values to exclude any abnormal outliers due to instrument noise using Eqs. (1) and (2):

$$
\begin{aligned}
& \operatorname{Int}^{+}\left(\operatorname{SSM}_{\text {sim }}\right)=\mu\left(\operatorname{SSM}_{\text {sim }}\right)+1.64 \sigma\left(\operatorname{SSM}_{\text {sim }}\right) \\
& \operatorname{Int}^{-}\left(\mathrm{SSM}_{\text {sim }}\right)=\mu\left(\mathrm{SSM}_{\text {sim }}\right)-1.64 \sigma\left(\mathrm{SSM}_{\mathrm{sim}}\right)
\end{aligned}
$$

Where Int+ and Int- are the upper and lower $90 \%$ limits of the confidence interval. Then a new ASCAT SSM data set is obtained using Eq. (3):

$\mathrm{SSM}=\frac{\mathrm{SSM}-\mathrm{Int}^{-}}{\mathrm{Int}^{+}-\mathrm{Int}^{-}}$

It is assumed that both modelled and in situ data sets do not have such outliers problem and they were rescaled using the maximum and minimum values of each individual times series considering the whole 2007-2008 period.

The SIM spatial resolution is $8 \mathrm{~km}$ and continental France is covered with 9892 grid points. The nearest neighbour technique is used to co-locate the SMOSMANIA stations with the closest SIM grid-point. The same technique is used to make a correspondence between ASCAT grid-points and SIM, ASCAT grid-points and the SMOSMANIA stations and also for the operational products from ECMWF and Météo-France. As in Albergel et al. (2009), only the descending (morning) ASCAT passes are used in this study, as better scores are obtained with those data (Wagner et al., 1999a, 2007a; Albergel et al., 2009). When considering ASCAT data, Kendall statistics $(\tau)$ and p-value (a measure of the correlation significance) are calculated. The Kendall $\tau$ is a non-parametric measure of correlation that assesses how well an arbitrary monotonic function could describe the relationship between two variables, without making any assumptions about the frequency distribution of the variables. It is used to measure the degree of correspondence between two rankings and assessing the significance of this correspondence. ASCAT data are downscaled from the $12.5 \mathrm{~km}$ equal grid spacing to a one kilometre scale thanks to the linear relation expressed by Eq. (4):

$\operatorname{SSM}^{\text {local }}(x, y, t)=c(x, y)+d(x, y) \times \operatorname{SSM}^{\text {regional }}(t)$

where local SSM at point $(x, y)$ is obtained using downscaling parameters $c$ and $d$ (previously derived from ASAR measurements) at point $(x, y)$ and using the regional SSM at time $t$. The downscaling parameters $\mathrm{c}$ and $\mathrm{d}$ were provided by TUWien and more details can be found in Wagner et al. (2008).

The two years 2007-2008 period is used for the evaluation of SIM and ASCAT soil moisture products. The common period for ALADIN, IFS, SIM and in situ data is from July 2008 to June 2009. All these SSM products are in units of $\mathrm{m}^{3} \mathrm{~m}^{-3}$, but they may correspond to soil surface layers 

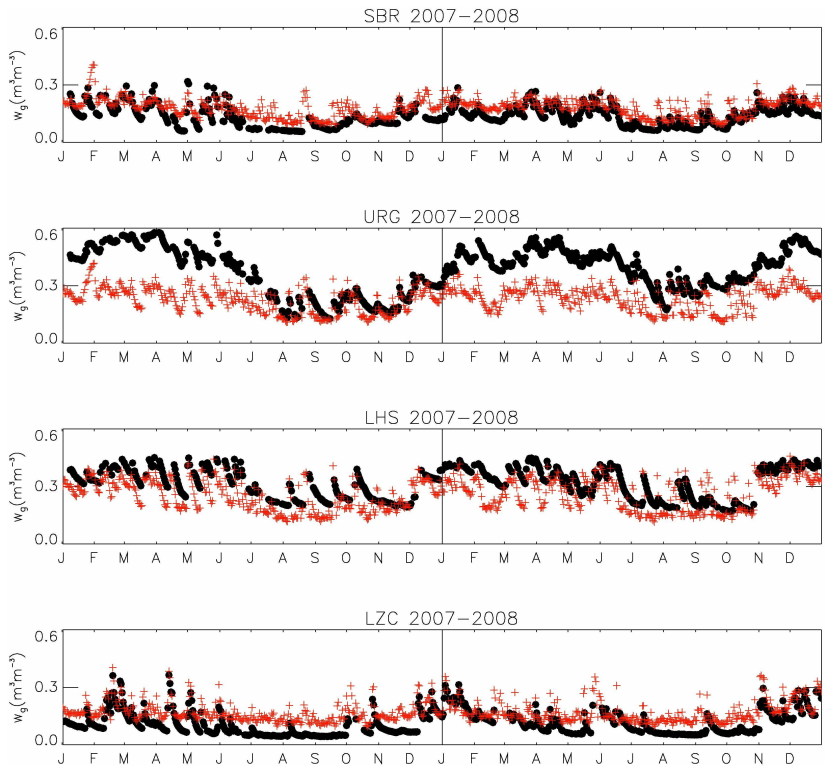

Fig. 3. Comparison between modelled SSM from the SIM model (red crosses) and in situ SSM (black dots) for four stations of the SMOSMANIA network (Sabres, Urgons, Lahas, and LézignanCorbières - SBR, URG, LHS, LZC, respectively) over a two year period (2007-2008).

with different thicknesses (a very thin surface layer for ALADIN and SIM, 0-7 $\mathrm{cm}$ for IFS, $5 \mathrm{~cm}$ for the SMOSMANIA stations). As the IFS uses a multilayer model (the H-TESSEL land surface scheme of ECMWF), the simulated root-zone soil moisture content $(7-28 \mathrm{~cm})$ can be compared to the in situ observations at $20 \mathrm{~cm}$.

\section{Results and discussion}

\subsection{Evaluation of the SIM model}

Figure 3 presents a comparison between the SSM values from the SIM model and the in situ SSM observations for four stations of the SMOSMANIA network over a twoyear period (2007-2008). The statistical scores are presented in Table 2 for all the stations. The comparison of the SIM with in situ data shows a good temporal correlation with $r$ values ranging from 0.60 to 0.78 , with an average of 0.70 and a standard deviation of 0.06 . Biases are ranging from -0.080 to $0.149 \mathrm{~m}^{3} \mathrm{~m}^{-3}$ (in situ minus model, i.e. the model tends to underestimate SSM) with an average of $0.030 \mathrm{~m}^{3} \mathrm{~m}^{-3}$ and standard deviation of $0.066 \mathrm{~m}^{3} \mathrm{~m}^{-3}$. The RMSE ranges from 0.053 to $0.174 \mathrm{~m}^{3} \mathrm{~m}^{-3}$, with an average value of $0.085 \mathrm{~m}^{3} \mathrm{~m}^{-3}$, and a standard deviation of $0.035 \mathrm{~m}^{3} \mathrm{~m}^{-3}$. Figure 3 shows that the SSM temporal variability of SIM is high, compared with the observations. A possible explanation is that the thickness of the surface soil layer modelled by SIM is less than $1 \mathrm{~cm}$, hence more sub-
Table 2. Main statistical scores for the comparison between modelled SSM from the SIM model and in situ SSM $(5 \mathrm{~cm})$ for the twelve stations of the SMOSMANIA network and for the SMOSREX site over a two-year period (2007-2008).

\begin{tabular}{lrrr}
\hline Stations & $r$ & $\begin{array}{r}\text { Bias } \\
\left(\mathrm{m}^{3} \mathrm{~m}^{-3}\right)\end{array}$ & $\begin{array}{r}\text { RMSE } \\
\left(\mathrm{m}^{3} \mathrm{~m}^{-3}\right)\end{array}$ \\
\hline SBR & 0.78 & -0.041 & 0.053 \\
URG & 0.67 & 0.149 & 0.174 \\
CRD & 0.70 & -0.080 & 0.090 \\
PRG & 0.73 & 0.042 & 0.067 \\
CDM & 0.77 & 0.085 & 0.098 \\
LHS & 0.71 & 0.060 & 0.085 \\
SVN & 0.64 & 0.027 & 0.073 \\
MNT & 0.64 & 0.118 & 0.137 \\
SFL & 0.77 & 0.001 & 0.052 \\
MTM & 0.60 & 0.058 & 0.075 \\
LZC & 0.77 & -0.055 & 0.068 \\
NBN & 0.66 & 0.004 & 0.049 \\
SMX & 0.64 & 0.031 & 0.082 \\
All stations & 0.70 & 0.030 & 0.085 \\
\hline
\end{tabular}

jected to rapid variations in response to rather small rain events than the in situ observations at $5 \mathrm{~cm}$. Also, the spatial interpolation process within SAFRAN may generate precipitation events, which are not observed at the local scale. However, on the basis of these results, it can be assumed that the SIM predictions may be used as a credible SSM data set to evaluate remotely sensed SSM estimates.

\subsection{Evaluation of ASCAT data}

\subsubsection{Using in situ data}

The statistical scores are presented in Table 3. As in Albergel et al. (2009) one station, MTM, located in a rather mountainous area (538 m a.s.l.) is not used because of the lack of usable satellite measurements. For the eleven remaining stations of the SMOSMANIA network and for the SMOSREX site used in this comparison, the correlation between the in situ observations and the satellite SSM estimates over the 2007-2008 2-yr period is very significant (Kendall p-values lower than $\left.10^{-4}\right)$. The usage of ASCAT data reprocessed over a grid (WARP-5), instead of raw orbit data, seems to limit the effect of the proximity of the Mediterranean Sea found by Albergel et al. (2009) for the two most eastward stations, LZC and NBN, which now have significant correlations. The $r$ values range from 0.47 to 0.71 with an average of 0.59 and a standard deviation of 0.07 . The lowest correlation is found for the station of MNT, and the presence of hilly terrains and forests may explain this result. Among the 12 stations, seven stations have $r$ values greater than 0.6. No systematic dry or wet bias is observed, with values ranging from -0.329 to 0.076 (dimensionless) and an average 
Table 3. Statistical scores for the comparison between either ASCAT and in situ (5 cm) or ASCAT and SIM surface soil moisture (dimensionless as SSM data where rescaled, see paragraph 2.4 Data preparation) over a two year period (2007-2008) for 11 stations of the SMOSMANIA network and for the SMOSREX site. The last row is for the average of the 12 stations.

\begin{tabular}{lcccccc}
\hline $\begin{array}{l}\text { Stations- (distance } \\
\text { between in situ }\end{array}$ & \multicolumn{2}{c}{$r$} & \multicolumn{2}{c}{ Bias (-) } & \multicolumn{2}{c}{ RMSE (-) } \\
station and the & & & & & & \\
nearest ASCAT grid- & & & & & & \\
point in km) & & & & & & \\
\hline & ASCAT & ASCAT & ASCAT & ASCAT & ASCAT & ASCAT \\
& vs & vs & vs & vs & vs & vs \\
& in situ & SIM & in situ & SIM & in situ & SIM \\
\hline SBR - 5.8 & 0.71 & 0.73 & -0.192 & -0.177 & 0.229 & 0.205 \\
URG - 4.4 & 0.64 & 0.69 & -0.115 & -0.284 & 0.229 & 0.320 \\
CRD - 4.2 & 0.63 & 0.71 & -0.329 & -0.175 & 0.357 & 0.224 \\
PRG - 5.4 & 0.59 & 0.71 & -0.051 & -0.112 & 0.209 & 0.197 \\
CDM - 4.5 & 0.63 & 0.69 & 0.033 & -0.066 & 0.195 & 0.179 \\
LHS - 3.6 & 0.62 & 0.64 & 0.040 & -0.011 & 0.217 & 0.188 \\
SVN - 6.8 & 0.60 & 0.65 & -0.220 & -0.107 & 0.278 & 0.199 \\
MNT - 5.2 & 0.47 & 0.57 & 0.031 & -0.085 & 0.219 & 0.210 \\
SFL - 2.3 & 0.51 & 0.59 & -0.051 & -0.023 & 0.245 & 0.204 \\
MTM & n/a & n/a & n/a & n/a & n/a & n/a \\
LZC - 6.5 & 0.61 & 0.63 & -0.121 & -0.067 & 0.202 & 0.157 \\
NBN - 5.4 & 0.54 & 0.56 & -0.052 & -0.072 & 0.211 & 0.170 \\
SMX - 6.8 & 0.52 & 0.64 & 0.076 & -0.084 & 0.253 & 0.198 \\
Averaged & 0.59 & 0.65 & -0.079 & -0.105 & 0.237 & 0.204 \\
scores & & & & & & \\
\hline
\end{tabular}

of -0.079 . As the average RMSE is 0.237 (dimensionless), and given the average dynamic range of $0.24 \mathrm{~m}^{3} \mathrm{~m}^{-3} \mathrm{ob}-$ served for the SMOSMANIA stations at a depth of $5 \mathrm{~cm}$, the average RMSE of the soil moisture retrieval is about $0.057 \mathrm{~m}^{3} \mathrm{~m}^{-3}$, close to the value of $0.06 \mathrm{~m}^{3} \mathrm{~m}^{-3}$ found in Albergel et al. (2009). The same analysis was performed for each season (Table 4) with similar results except for summer, presenting lower $r$ values ( 0.43 on average). In summer, more localised convective precipitation may occur in Southwestern France. Moreover, high temperatures and enhanced evaporation rates observed at summer can lead to quick variations of soil moisture as seen by ASCAT (thin soil surface layer) after a rainfall event. Better correlations are obtained in autumn with an average $r$ of 0.61 .

\subsubsection{Using data from land surface models}

In this section, the ASCAT SSM data set is compared with the SIM data set over the same period as in the previous Sect. 3.2.1 (2007-2008). Table 3 presents the statistical scores. The $r$ values range from 0.56 to 0.73 with an average of 0.65 and a standard deviation of 0.06 . The mean bias is always negative with an average value of -0.105 (SIM minus ASCAT, i.e. the SIM SSM tends to be drier) and a mean error RMSE $=0.204$. As the average dynamic range of SSM modelled by SIM for the considered stations is $0.31 \mathrm{~m}^{3} \mathrm{~m}^{-3}$, an average RMSE of the soil moisture retrieval is about $0.063 \mathrm{~m}^{3} \mathrm{~m}^{-3}$.

At the location of the SMOSMANIA stations, the ASCAT SSM always correlates better with the SIM estimates than with the in situ observations, over the whole 2007-2008 period and also per season. The two main factors that may decrease the correlation between in situ and SIM SSM are less critical for ASCAT vs. SIM: (1) the thin surface layer used in SIM (less than $1 \mathrm{~cm}$ ) is more consistent with the thin remotely sensed depth by ASCAT at C-band ( 0.5 to $2 \mathrm{~cm})$, than the in situ observations at a depth of $5 \mathrm{~cm}$; (2) the interpolated atmospheric forcing (e.g. precipitation) provided by the SAFRAN analysis and used in SIM ( $8 \mathrm{~km}$ resolution) may be more representative of the area observed in an ASCAT pixel than local observations. Moreover, it was shown in Sect. 3.1 that SIM is able to capture the SSM dynamic with a good accuracy. It can be used as an additional tool for the evaluation of remotely sensed soil moisture estimates at a larger scale. Figure 4 illustrates the comparison between ASCAT and SIM SSM. Over this two year period, it is possible to appreciate the seasonal cycles of SSM, i.e. with dry (summer) and wet (winter) periods for both SSM data sets and for all the considered stations. The seasonal cycle seems to be more marked for the SIM SSM. 
Table 4. Averaged seasonal statistical scores for 11 stations of the SMOSMANIA network and for the SMOSREX site for the comparison between (i) ASCAT vs. in situ (5 cm) SSM and (ii) ASCAT vs. SIM SSM over a two year period.

\begin{tabular}{|c|c|c|c|c|c|c|c|c|}
\hline & \multicolumn{2}{|c|}{$r$} & \multicolumn{2}{|c|}{ Bias (-) } & \multicolumn{2}{|c|}{$\operatorname{RMSE}(-)$} & \multicolumn{2}{|c|}{ Estimated Error $\left(\mathrm{m}^{3} \mathrm{~m}^{-3}\right)$} \\
\hline & $\begin{array}{l}\text { In situ vs. } \\
\text { ASCAT }\end{array}$ & $\begin{array}{c}\text { SIM } \\
\text { vs. ASCAT }\end{array}$ & $\begin{array}{l}\text { In situ vs. } \\
\text { ASCAT }\end{array}$ & $\begin{array}{c}\text { SIM } \\
\text { vs. AASCAT }\end{array}$ & $\begin{array}{l}\text { In situ vs. } \\
\text { SCAT }\end{array}$ & $\begin{array}{c}\text { SIM } \\
\text { vs. ASCAT }\end{array}$ & $\begin{array}{c}\text { In situ vs. } \\
\text { ASCAT }\end{array}$ & $\begin{array}{c}\text { SIM } \\
\text { vs. ASCAT }\end{array}$ \\
\hline Winter & 0.53 & 0.61 & -0.022 & -0.069 & 0.197 & 0.177 & 0.047 & 0.055 \\
\hline Spring & 0.51 & 0.57 & 0.036 & -0.040 & 0.221 & 0.177 & 0.053 & 0.055 \\
\hline Summer & 0.43 & 0.53 & -0.161 & -0.126 & 0.260 & 0.235 & 0.062 & 0.073 \\
\hline Autumn & 0.61 & 0.69 & -0.146 & -0.117 & 0.239 & 0.203 & 0.057 & 0.063 \\
\hline All & 0.59 & 0.65 & -0.079 & -0.105 & 0.237 & 0.204 & 0.058 & 0.062 \\
\hline
\end{tabular}
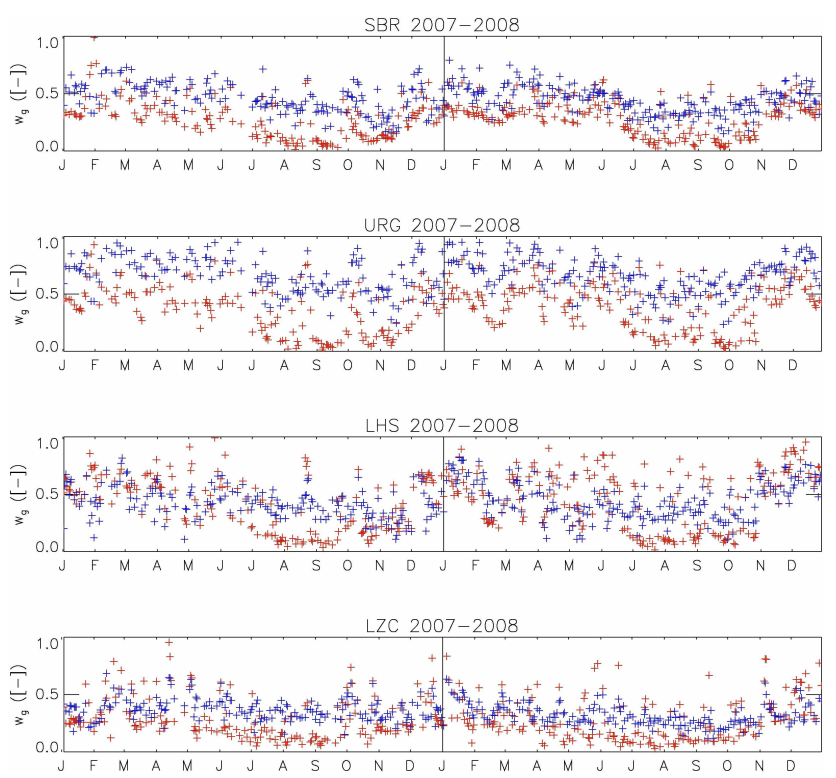

Fig. 4. Comparison between modelled SSM from the SIM model (red crosses) and ASCAT SSM estimates (blue crosses) for four stations of the SMOSMANIA network (Sabres, Urgons, Lahas, and Lézignan-Corbières - SBR, URG, LHS, LZC, respectively) over a two year period (2007-2008).

Finally, this representation of the seasonal cycle (Figs. 3 and 4) is completed by Fig. 5. The latter presents the probability density function of the three SSM data sets (in situ, ASCAT, SIM) over the LHS station. A bi-modal shape, characteristic of long SSM time series, is observed for the three data sets. A similar bi-modal pdf is observed for the other stations (not shown). It is caused by the accumulation of high SSM values in wet conditions (e.g. winter and springtime) and of low SSM values in dry conditions (e.g. summertime and the autumn) illustrated by Figs. 3 and 4 .
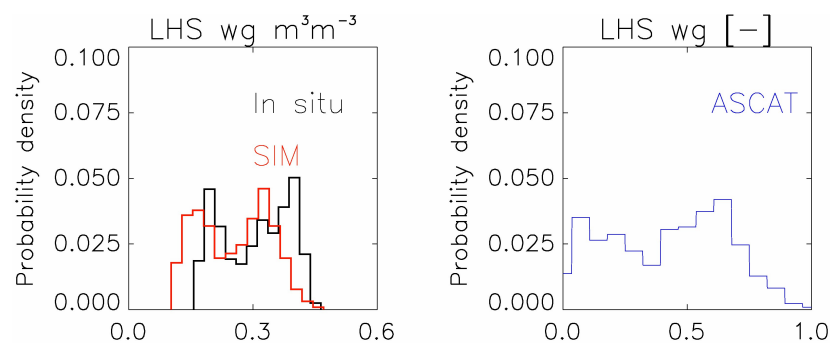

Fig. 5. Probability density function of SSM for the three data sets used in this study, (left) in situ and SIM $\left(\mathrm{m}^{3} \mathrm{~m}^{-3}\right)$ and (right) ASCAT (relative humidity) over a two year period 2007-2008 for the Lahas (LHS) station.

\subsubsection{ASCAT downscaled product}

Over the 2007-2008 period, the comparison could be made only for nine of the twelve SMOSMANIA stations and the SMOSREX site. As in Sect. 3.2.1, the station of MTM is not used. Moreover, the covered area is limited by the availability of the downscaling parameter database derived from ASAR. The area close to the Mediterranean sea is not covered, and therefore the stations of LZC and NBN could not be considered. A total of 150 ASCAT swaths covering all the considered stations at 150 dates in 2007 or 2008 are used for this analysis. As Eq. (4), used to downscale the ASCAT products at a one kilometre scale, is linear, it is not of interest to reproduce the same comparison as in Sect. 3.2.1 with the in situ data. However, bias and RMSE were investigated. This analysis was done through different steps:

- step 1: Over the considered 2-year period, the ASCAT swaths covering the 10 considered stations (9 SMOSMANIA + SMOSREX) are isolated and analyzed separately.

- step 2: For each of these swaths (a total of 150), spatial correlations are calculated between the available in situ data (always 10 stations) and either ASCAT coarse resolution or downscaled estimates, resulting in 150 correlation values in both cases. 

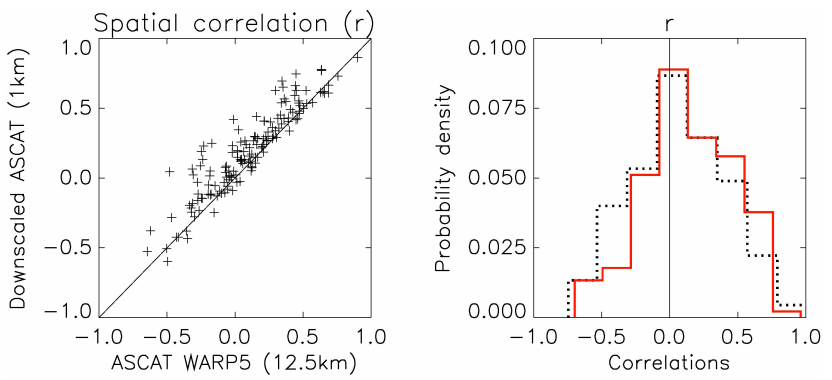

Fig. 6. Spatial correlation between ASCAT SSM estimates and in situ SSM vs. spatial correlation between downscaled ASCAT SSM estimates and in situ SSM, 150 ASCAT swaths (i.e. days) are considered: (left) scatterplot, (right) probability densities of for the ASCAT SSM (dotted line), and for the downscaled ASCAT SSM (red line).

- step 3: The 150 correlations values between in situ and coarse resolution ASCAT estimates are compared with the 150 correlations values between in situ and downscaled ASCAT estimates.

It permits to appreciate the added value of the downscaled product. For the considered group of stations (10 stations), the following scores are obtained with the low resolution (WARP-5, $12.5 \mathrm{~km}$ ) ASCAT grid point (averaged for all stations): bias $=-0.078$ and $\mathrm{RMSE}=0.243$. With the downscaled product, similar scores are obtained: bias $=-0.071$ and $\mathrm{RMSE}=0.257$.

The same spatial correlation is calculated for each considered date and the nearest low resolution (WARP-5, 12.5 km) ASCAT grid point. The spatial correlations derived from the low resolution product are compared with those derived from the downscaled product in Fig. 6 (left). In 115 out of the 150 swaths (about 77\%), correlations are greater when downscaled ASCAT estimates are used. This result underlines the added value of the downscaled product. However, while for most swaths, spatial correlations are improved, the average score for all swaths is not very different. This is illustrated by Fig. 6 (right) where the probability density of the correlation between in situ SSM and either low resolution (WARP$5,12.5 \mathrm{~km}$ ) or downscaled ASCAT products is presented.

\subsection{Evaluation of operational NWP soil moisture products}

In this section, three different NWP soil moisture analyses from ECMWF and Météo- France are evaluated thanks to in situ soil moisture measurements at twelve stations of the SMOSMANIA network over a one year period (July 2008June 2009). The operational analyses from Météo-France and ECMWF are based on the OI technique and the use of $T_{2 \mathrm{~m}}$ and $\mathrm{RH}_{2 \mathrm{~m}}$. However, the LSM is different: the $\mathrm{H}$ TESSEL LSM used in the ECMWF IFS is a multilayer model with a surface layer of $7 \mathrm{~cm}$, whereas ISBA in the ALADIN
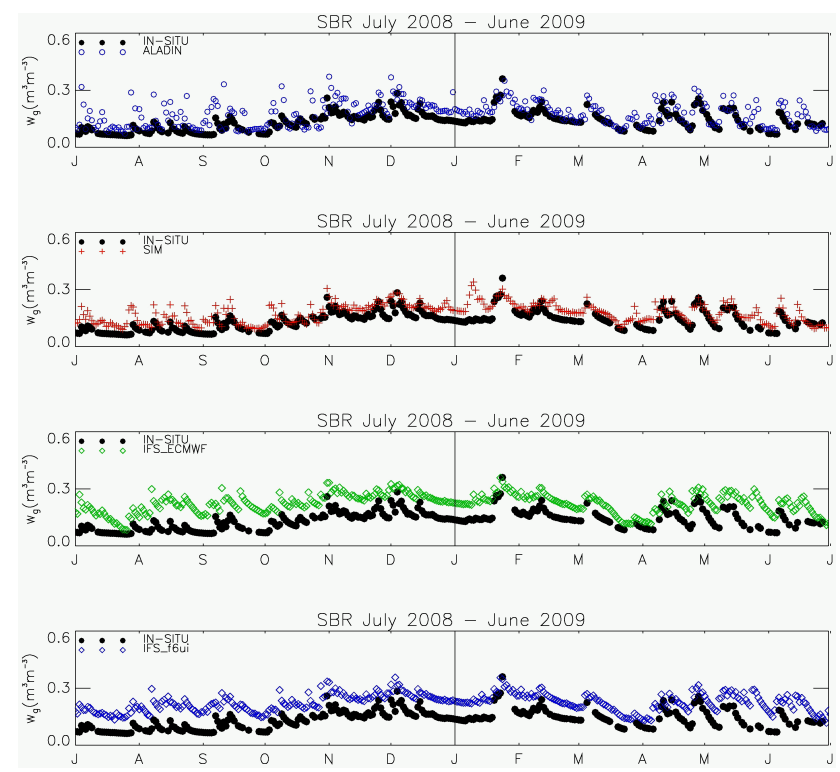

Fig. 7. Comparison of in situ surface soil moisture at Sabres (SBR) with simulations provided by (from top to bottom): (i) the ALADIN operational NWP model (OI analysis, $T_{2} \mathrm{~m}, \mathrm{RH}_{2 \mathrm{~m}}$ ), (ii) the SIM hydro-meteorological model, (iii) the ECMWF IFS (OI analysis, $T_{2 \mathrm{~m}}, \mathrm{RH}_{2 \mathrm{~m}}$ ) and (iv) the ECMWF IFS using a SEKF analysis (ASCAT SSM, $T_{2 \mathrm{~m}}, \mathrm{RH}_{2 \mathrm{~m}}$ ).

system of Météo-France considers a very thin surface layer. The in situ SSM is observed at a depth of $5 \mathrm{~cm}$, which is more in line with the physics of H-TESSEL. In addition to these operational data, a third analysis is evaluated, derived from the research IFS F6ui ECMWF system, based on a simplified Extended Kalman Filter (Drusch et al., 2009) assimilating $T_{2 \mathrm{~m}}$ and $\mathrm{RH}_{2 \mathrm{~m}}$ and ASCAT SSM estimates. Time series of SSM are shown in Fig. 7, for the most westward station of the SMOSMANIA network (SBR), over the one year period considered for this study. The SSM derived from SIM is shown as well. The temporal SSM dynamic is well captured by the different models. The ALADIN SSM presents a higher variability than the in situ observations and the other analyses products. The two ECMWF products present a higher bias while correlating better with the in situ observations. Standard deviations for ALADIN, SIM, new product of ECMWF (IFS F6ui) and the operational one (IFS ECMWF) are 0.059, $0.050,0.044$ and $0.049 \mathrm{~m}^{3} \mathrm{~m}^{-3}$, respectively. The statistical scores are presented in Table 5. For nine stations over a total of twelve, the IFS F6ui product gives better results compared to the IFS ECMWF, with $r$ values higher than 0.79. An evaluation of the analysed SSM values is shown in Fig. 8, presenting $r$ values, mean bias and RMSE scores. The two ECMWF SSM products correlate better with in situ data than all other products, while the Météo-France ALADIN product is slightly less biased, with mean bias values of 0.022 , $0.037,-0.036$ and $-0.041 \mathrm{~m}^{3} \mathrm{~m}^{-3}$ for ALADIN, SIM, IFS 
Table 5. Evaluation of operational surface soil moisture products from meteorological services using the SMOSMANIA surface soil moisture (5 cm depth) over a one year period (July 2008-June 2009). The last row shows the average of the 12 stations.

\begin{tabular}{|c|c|c|c|c|c|c|c|c|c|c|c|c|}
\hline & \multicolumn{4}{|c|}{$r$} & \multicolumn{4}{|c|}{$\operatorname{Bias}\left(\mathrm{m}^{3} \mathrm{~m}^{-3}\right)$} & \multicolumn{4}{|c|}{$\operatorname{RMSE}\left(\mathrm{m}^{3} \mathrm{~m}^{-3}\right)$} \\
\hline & ALADIN & $\begin{array}{c}\text { IFS } \\
\text { ECMWF }\end{array}$ & $\begin{array}{l}\text { IFS } \\
\text { F6ui }\end{array}$ & SIM & ALADIN & $\begin{array}{c}\text { IFS } \\
\text { ECMWF }\end{array}$ & $\begin{array}{l}\text { IFS } \\
\text { F6ui }\end{array}$ & SIM & ALADIN & $\begin{array}{c}\text { IFS } \\
\text { ECMWF }\end{array}$ & $\begin{array}{l}\text { IFS } \\
\text { F6ui }\end{array}$ & SIM \\
\hline SBR & 0.73 & 0.77 & 0.83 & 0.80 & -0.040 & -0.089 & -0.089 & -0.043 & 0.059 & 0.095 & 0.093 & 0.053 \\
\hline URG & 0.56 & 0.75 & 0.83 & 0.72 & 0.187 & 0.060 & 0.060 & 0.180 & 0.204 & 0.092 & 0.090 & 0.192 \\
\hline CRD & 0.69 & 0.81 & 0.82 & 0.78 & -0.092 & -0.214 & -0.214 & -0.073 & 0.108 & 0.216 & 0.216 & 0.083 \\
\hline PRG & 0.61 & 0.83 & 0.80 & 0.80 & 0.062 & -0.022 & -0.024 & 0.067 & 0.097 & 0.049 & 0.052 & 0.082 \\
\hline CDM & 0.60 & 0.78 & 0.84 & 0.78 & 0.074 & 0.004 & 0.001 & 0.087 & 0.106 & 0.045 & 0.042 & 0.100 \\
\hline LHS & 0.65 & 0.86 & 0.86 & 0.82 & 0.022 & -0.028 & -0.038 & 0.033 & 0.083 & 0.061 & 0.069 & 0.064 \\
\hline SVN & 0.50 & 0.75 & 0.79 & 0.69 & -0.022 & -0.077 & -0.086 & 0.037 & 0.105 & 0.108 & 0.115 & 0.088 \\
\hline MNT & 0.61 & 0.83 & 0.83 & 0.75 & 0.032 & 0.121 & 0.100 & 0.097 & 0.132 & 0.078 & 0.077 & 0.141 \\
\hline SFL & 0.69 & 0.90 & 0.89 & 0.80 & 0.005 & -0.049 & -0.060 & 0.000 & 0.070 & 0.060 & 0.071 & 0.053 \\
\hline MTM & 0.59 & 0.85 & 0.84 & 0.75 & 0.015 & -0.057 & -0.059 & 0.046 & 0.070 & 0.079 & 0.080 & 0.069 \\
\hline LZC & 0.66 & 0.80 & 0.86 & 0.85 & -0.044 & -0.142 & -0.146 & -0.039 & 0.078 & 0.151 & 0.152 & 0.057 \\
\hline NBN & 0.62 & 0.88 & 0.89 & 0.74 & 0.070 & 0.062 & 0.066 & 0.057 & 0.070 & 0.062 & 0.066 & 0.057 \\
\hline SMX & $\mathrm{n} / \mathrm{a}$ & $\mathrm{n} / \mathrm{a}$ & $\mathrm{n} / \mathrm{a}$ & $\mathrm{n} / \mathrm{a}$ & $\mathrm{n} / \mathrm{a}$ & $\mathrm{n} / \mathrm{a}$ & $\mathrm{n} / \mathrm{a}$ & $\mathrm{n} / \mathrm{a}$ & $\mathrm{n} / \mathrm{a}$ & $\mathrm{n} / \mathrm{a}$ & $\mathrm{n} / \mathrm{a}$ & $\mathrm{n} / \mathrm{a}$ \\
\hline $\begin{array}{l}\text { Averaged } \\
\text { scores }\end{array}$ & 0.63 & 0.82 & 0.84 & 0.77 & 0.022 & -0.036 & -0.041 & 0.037 & 0.099 & 0.091 & 0.094 & 0.087 \\
\hline
\end{tabular}

ECMWF and IFS F6ui, respectively. Figure 9 completes the evaluation by presenting the $r$ values, mean bias and RMSE scores of the two ECMWF products for the second $(7-28 \mathrm{~cm})$ layer of soil, based on in situ observations at $20 \mathrm{~cm}$. The IFS F6ui analysis correlates better with in situ data than the IFS ECMWF product for both SSM and root zone soil moisture (Table 6). The average $r$ between the IFS ECMWF rootzone soil moisture and in situ observations (at $20 \mathrm{~cm}$ ) is 0.81 , against 0.84 for IFS F6ui.

The biases observed for both ECMWF and Météo-France products might be caused by shortcomings in the employed soil characteristics and pedotransfer functions, and also by the difficulty to represent the spatial heterogeneity of these properties. In particular, the soil texture map currently used at ECMWF is from the Food and Agricultural Organization (FAO) dataset (FAO, 2003) and the implementation of a new map such as the new comprehensive Harmonized World Soil Database (HWSD) (FAO, 2009) could lead to better results. For example, the station of CRD corresponds to a sandy soil, whereas the texture used by the model for the corresponding pixel is loamy. This may explain the high bias and RMSE for this station (see Fig. 8).

Considering the second layer of soil of the ECMWF analysis, the correlation is better for the IFS F6ui products using ASCAT SSM estimates, except for the station of MTM. This station, located in a mountainous area, is not used in Sect. 3.2.1 for the comparison between in situ and ASCAT due to the lack of satellite measurements. This may explain the low scores for this station with the new product of ECMWF.
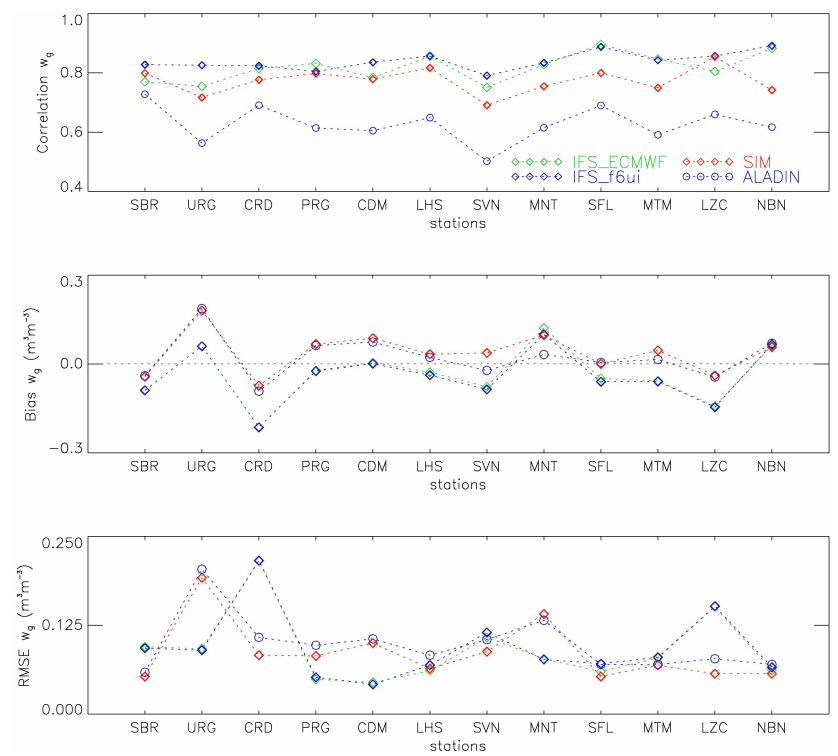

Fig. 8. Score of the Météo-France and ECMWF SSM analyses using the twelve stations of the SMOSMANIA network. From top to bottom: correlation, mean bias and RMSE. In situ SSM observations are used to evaluate SSM analysis from Météo-France (ALADIN in blue dots and SIM in red diamonds) and ECMWF (Optimal Interpolation with $T_{2} \mathrm{~m}$ and $\mathrm{RH}_{2} \mathrm{~m}$ in green diamonds, SEKF with $T_{2} \mathrm{~m}$ and $\mathrm{RH}_{2} \mathrm{~m}$ and ASCAT SSM estimates in blue diamonds). 
Table 6. Evaluation of operational soil moisture products from ECMWF for the second layer of soil (7-28 cm) using the SMOSMANIA in situ soil moisture $(20 \mathrm{~cm}$ depth) over a one year period (July 2008-June 2009). The last row is for the average of the 12 stations.

\begin{tabular}{|c|c|c|c|c|c|c|}
\hline & \multicolumn{2}{|l|}{$r$} & \multicolumn{2}{|c|}{$\operatorname{Bias}\left(\mathrm{m}^{3} \mathrm{~m}^{-3}\right)$} & \multicolumn{2}{|c|}{$\operatorname{RMSE}\left(\mathrm{m}^{3} \mathrm{~m}^{-3}\right)$} \\
\hline & IFS & IFS & IFS & IFS & IFS & IFS \\
\hline & ECMWF & F6ui & ECMWF & F6ui & ECMWF & F6ui \\
\hline SBR & 0.75 & 0.80 & -0.063 & -0.058 & 0.100 & 0.094 \\
\hline URG & 0.79 & 0.86 & -0.010 & -0.007 & 0.032 & 0.027 \\
\hline CRD & 0.73 & 0.78 & -0.213 & -0.214 & 0.219 & 0.219 \\
\hline PRG & 0.70 & 0.71 & -0.040 & -0.041 & 0.050 & 0.050 \\
\hline CDM & 0.71 & 0.82 & 0.039 & 0.038 & 0.071 & 0.065 \\
\hline LHS & 0.78 & 0.83 & 0.048 & 0.038 & 0.065 & 0.056 \\
\hline SVN & 0.85 & 0.89 & -0.106 & -0.115 & 0.111 & 0.118 \\
\hline MNT & 0.85 & 0.89 & -0.059 & -0.067 & 0.079 & 0.076 \\
\hline SFL & 0.93 & 0.94 & -0.068 & -0.079 & 0.074 & 0.082 \\
\hline MTM & 0.86 & 0.77 & 0.005 & -0.002 & 0.032 & 0.039 \\
\hline LZC & 0.87 & 0.86 & -0.109 & -0.116 & 0.117 & 0.124 \\
\hline NBN & 0.96 & 0.96 & -0.035 & -0.045 & 0.043 & 0.051 \\
\hline SMX & $\mathrm{n} / \mathrm{a}$ & $\mathrm{n} / \mathrm{a}$ & $\mathrm{n} / \mathrm{a}$ & $\mathrm{n} / \mathrm{a}$ & $\mathrm{n} / \mathrm{a}$ & $\mathrm{n} / \mathrm{a}$ \\
\hline $\begin{array}{l}\text { Averaged } \\
\text { scores }\end{array}$ & 0.81 & 0.84 & -0.051 & -0.056 & 0.083 & 0.083 \\
\hline
\end{tabular}
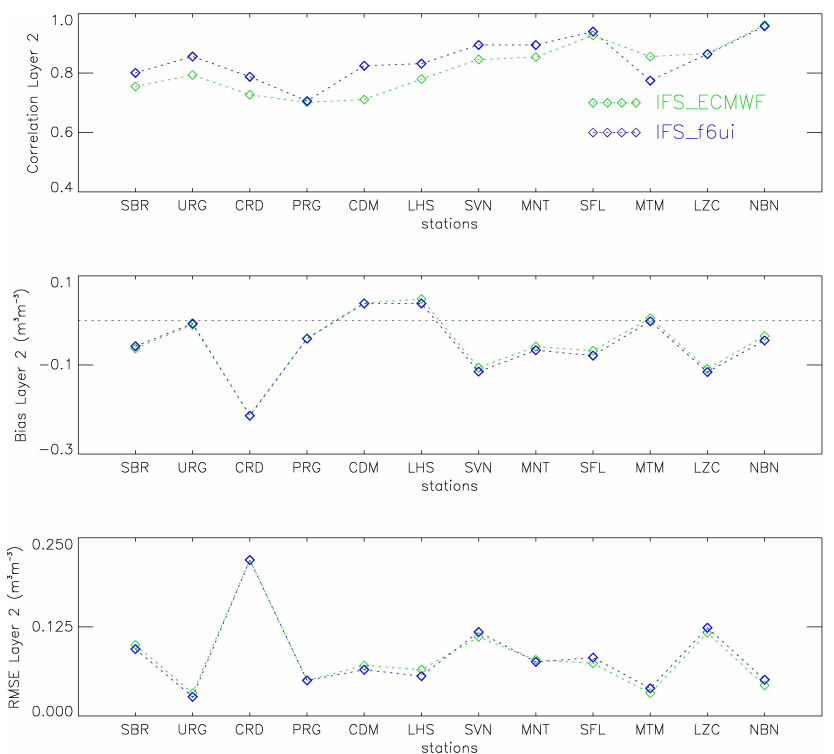

Fig. 9. Evaluation of the ECMWF root-zone $(7-28 \mathrm{~cm})$ soil moisture analysis using the soil moisture observations at $20 \mathrm{~cm}$ of the twelve stations of the SMOSMANIA network. From top to bottom: correlation, mean bias and RMSE.

\section{Conclusions}

In this study, several surface soil moisture (SSM) data sets were evaluated using in situ observations in Southwestern France. In situ observations at a depth of $5 \mathrm{~cm}$ for the stations of the SMOSMANIA network, and surface soil moisture in- tegrated from 0 to $6 \mathrm{~cm}$ at the SMOSREX station, were used to evaluate ASCAT and SIM soil moisture estimates. SIM generally was in good agreement with ground observations. Although SIM does not consider any data assimilation into the land surface model, SIM uses an atmospheric analysis (SAFRAN) based on numerous observations from more than 1000 meteorological stations and more than 3500 daily rain gauges. Regarding ASCAT estimates, this study confirms that even if local in situ observations of surface soil moisture do not measure the same quantity as coarse resolution remotely sensed products, significant correlations can be observed between the two measures. These correlations can be used to monitor the quality of satellite SSM estimates. The soil moisture analysis from the SIM model could be used to complete the evaluation as the SSM temporal dynamic was well represented by SIM. Estimates of the RMSE of the ASCAT SSM product using either in situ or modelled SSM values as a reference are very close: 0.057 and $0.063 \mathrm{~m}^{3} \mathrm{~m}^{-3}$ respectively. The downscaled ASCAT product is promising as it appeared that the downscaling improved the spatial correlation with in situ data.

Finally, NWP SSM analyses from ECMWF (IFS) and Météo-France (ALADIN) were assessed. In general, they reproduced well the temporal dynamic of the observed SSM, with a higher variability of the ALADIN analysis. The physics of the land surface scheme used in the IFS, a multilayer model with a first soil layer of a few centimetres $(0$ $7 \mathrm{~cm}$ ), was more consistent with the characteristics of the in situ observations. This may explain why the IFS SSM correlated better with in situ data compared to the ALADIN SSM, which uses the force-restore version of the ISBA LSM with 
a thin surface layer. The NWP models used in this study do not assimilate rainfall (the main driver of the soil moisture temporal pattern), but the information contained in meteorological observations of air temperature and air humidity close to the surface is used to analyse soil moisture. This analysis is more efficient in data-rich areas like southwestern France. In the ECMWF IFS used in operation in 2009, the soil moisture analysis was based on observed screen-level parameters $\left(T_{2 \mathrm{~m}}, \mathrm{RH}_{2 \mathrm{~m}}\right)$ and the assimilation technique used was the optimal interpolation (OI). An advanced surface data assimilation system (IFS_f6ui), based on a simplified extended Kalman filter (SEKF), screen-level parameters and ASCAT estimates, was evaluated, also. The differences between both analyses were the technique (OI or SEKF) and, for the latter, the use of ASCAT estimates. For the considered period and spatial resolution (T799: $23 \mathrm{~km}$ ), only those products were available. Therefore, while the global added-value of the new analysis and observations was demonstrated, the contribution of the new algorithm was not distinguished from the ASCAT contribution. At a coarser spatial resolution (T255: $80 \mathrm{~km}$ ) and over a one-year period (December 2008 to November 2009) de Rosnay et al. $(2009,2010)$ found that while the ECMWF soil moisture was in good agreement with the SMOSMANIA ground observations (mean correlation values higher than 0.78 for the two first soil layers) the effect of SEKF vs. OI was much stronger than that related to the assimilation of the ASCAT SSM product (mean correlations values higher than 0.84 for ECMWF IFS and IFS_f6ui). The ASCAT data set used in this study for the cross evaluation, and in the ECMWF analysis, was processed with ERSderived parameters. Very recent studies (Brocca et al., 2010a, b) reported that new ASCAT SSM estimates processed using model parameters calculated from ASCAT observations provided more consistent soil moisture estimates. The use of this new data set is under way at Météo-France.

Acknowledgements. The work of C. Albergel was supported by Centre National d'Etudes Spatiales (CNES) and Météo-France. The development of the SMOSMANIA network was co-funded by Météo-France, CNES and ESA. The SMOSREX project was co-funded by the "Programme National de Télédétection Spatiale" and by the "Programme Terre Océan Surface Continentales et Atmosphère" (CNES), and by participants to the experiment: CESBIO (CNES, CNRS, IRD, UPS), CNRM/GAME (MétéoFrance, CNRS), INRA, and ONERA, all in the framework of the SMOS science preparatory program. The work on soil moisture analysis in NWP systems, was performed in the framework of the GEOLAND2 project, co-funded by the European Commission within the GMES initiative in FP7, and in the framework of the EUMETSAT H-SAF project.

Edited by: E. Morin

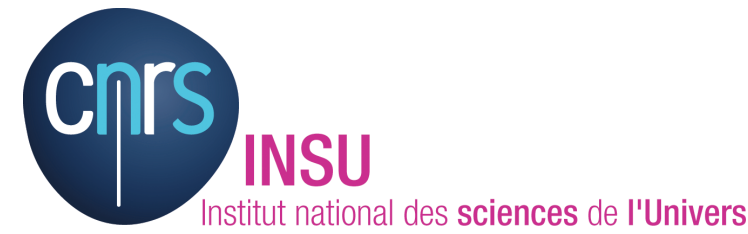

The publication of this article is financed by CNRS-INSU.

\section{References}

Albergel, C., Rüdiger, C., Pellarin, T., Calvet, J.-C., Fritz, N., Froissard, F., Suquia, D., Petitpa, A., Piguet, B., and Martin, E.: From near-surface to root-zone soil moisture using an exponential filter: an assessment of the method based on in-situ observations and model simulations, Hydrol. Earth Syst. Sci., 12, 1323-1337, doi:10.5194/hess-12-1323-2008, 2008.

Albergel, C., Rüdiger, C., Carrer, D., Calvet, J.-C., Fritz, N., Naeimi, V., Bartalis, Z., and Hasenauer, S.: An evaluation of ASCAT surface soil moisture products with in-situ observations in Southwestern France, Hydrol. Earth Syst. Sci., 13, 115-124, doi:10.5194/hess-13-115-2009, 2009.

Albergel, C., Calvet, J.-C., Gibelin, A.-L., Lafont, S., Roujean, J.L., Berne, C., Traullé, O., and Fritz, N.: Observed and modelled ecosystem respiration and gross primary production of a grassland in southwestern France, Biogeosciences, 7, 1657-1668, doi:10.5194/bg-7-1657-2010, 2010.

Artinyan, E., Habets, F., Noilhan, J., Ledoux, E., Dimitrov, D., Martin, E., and Le Moigne, P.: Modelling the water budget and the riverflows of the Maritsa basin in Bulgaria, Hydrol. Earth Syst. Sci., 12, 21-37, doi:10.5194/hess-12-21-2008, 2008.

Attema, E. W. P.: The active microwave instrument onboard the ERS-1 satellite, Proc. IEEE, 20, 79(6), 791-799, 1991.

Balsamo, G., Viterbo, P., Beljaars, A., van den Hurk, B., Hirschi, M., Betts, A. K., and Scipal, K.: A revised hydrology for the ECMWF model: Verification from field site to terrestrial water storage and impact in the ECMWF-IFS, J. Hydrometeor., 10, 623-643, doi:10.1175/2008JHM1068.1, 2009.

Bartalis, Z., Wagner, W., Naeimi, V., Hasenauer, S., Scipal, K., Bonekamp, H, Figa, J., and Anderson, C.: Initial soil moisture retrievals from the METOP-A advanced Scatterometer (ASCAT), Geophys. Res. Lett., 34, L20401, doi:10.1029/2007GL031088, 2007a.

Bartalis, Z., Hasenauer, S., Naeimi, V., and Wagner, W.: WARPNRT 2.0 Reference Manual, ASCAT Soil Moisture Report Series, No. 14, Institute of Photogrammetry and Remote Sensing, Vienna University of Technology, Austria, 26, available at: http://www.ipf.tuwien.ac.at/radar/ascat/report_series/ 14_WARPNRT\%202.0\%20Reference\%20Manual_v1.0.pdf, (last access: November 2010), 2007b.

Bélair, S., Crevier, L.-P., Mailhot, J., Bilodeau, B., and Delage, Y.: Operational implementation of the ISBA land surface scheme in the Canadian regional weather forecast model, part 1: warm season results, J. Hydrometeorol., 4, 352-370, 2003.

Boone, A., Calvet, J.-C., and Noilhan, J.: Inclusion of a third soil layer in a land surface scheme using the force-restore method, J. Appl. Meteorol., 38, 1611-1630, 1999.

Boone, A. and Etchevers, P.: An inter comparison of three snow schemes of varying complexity coupled to the same land-surface 
model: local scale evaluation at an Alpine site, J. Hydrometeorol., 2, 374-394, 2001.

Brocca, L., Melone, F., Moramarco, T., Wagner, W., and Hasenauer, S.: ASCAT Soil Wetness Index validation through insitu and modeled soil moisture data in central Italy, Remote Sens. Environ., 114(11), 2745-2755, doi:10.1016/j.rse.2010.06.009, 2010a.

Brocca, L., Hasenauer, S., de Rosnay, P., Melone, F., Moramarco, T., Matgen, P., Martínez-Fernández, J., Llorens, P., Latron, J., and Martin, C.: Consistent validation of H-SAF soil moisture satellite and model products against ground measurements for selected sites in Europe. Final report for the $\mathrm{H}-$ SAF project. Available at http://www.meteoam.it/modules/hsaf/ documents/reference/HSAF_AS_09_03_final_report.pdf, 56 pp., $2010 \mathrm{~b}$

Calvet, J.-C., Noilhan, J., Roujean, J.-L., Bessemoulin, P., Cabelguenne, M., Olioso, A., and Wigneron, J.-P.: An interactive vegetation SVAT model tested against data from six contrasting sites, Agr. Forest Meteorol., 92, 73-95, 1998.

Calvet, J.-C., Fritz, N., Froissard, F., Suquia, D., Petitpa, A., and Piguet, B.: in situ soil moisture observations for the CAL/VAL of SMOS: the SMOSMANIA network, International Geoscience and Remote Sensing Symposium, IGARSS, Barcelona, Spain, 1196-1199, doi:10.1109/IGARSS.2007.4423019, 2007.

Calvet, J.-C., Wigneron, J.-P., Walker, J., Karbou, F., Chanzy, A., and Albergel, C.: Sensitivity of passive microwave observations to soil moisture and vegetation water content: Lband to W-band, IEEE Trans. Geosci. Remote. Sens., in press, doi:10.1109/TGRS.2010.2050488, 2010.

de Rosnay, P., Calvet, J.-C., Kerr, Y., Wigneron, J.-P., Lemaître, F. et al.: SMOSREX: a long term field campaign experiment for soil moisture and land surface processes remote sensing, Remote Sens. Environ., 102, 377-389, 2006.

de Rosnay, P., Drusch, M., Balsamo, G., Beljaars, A., Isaksen, L., Vasiljevic, D., Albergel, C., and Scipal, K.: Advances in land data assimilation at ECMWF, Proceeding of the ECMWF/GLASS Workshop on Land Surface, Reading, UK, 8 pp., 9-12 November, 2009.

de Rosnay P., J. Muñoz Sabater, G. Balsamo, M. Drusch, K. Scipal, C. Albergel, D. Vasiljevic, A. Beljaars, and L. Isaksen: Use of satellite data for soil moisture analysis at ECMWF, ESA Living Planet Symposium, Bergen, Norway, 28 June-2 July, 2010.

Deardorff, J. W.: Efficient prediction of ground surface temperature and moisture with inclusion of a layer of vegetation, J. Geophys. Res., 83(C4), 1889-1903, 1978.

Dirmeyer, P. A., Dolman, A. J., and Sato, N.: The pilot phase of the global soil wetness project, B. Am. Meteorol. Soc., 80, 851-878, 1999.

Drusch, M. and Viterbo, P.: Assimilation of screen-level variables in ECMWF's integrated forecast system: a study on the impact on the forecast quality and analyzed soil moisture, Mon. Weather Rev., 135, 300-314, 2007.

Drusch, M., Scipal, K., de Rosnay, P., Balsamo, G., Anderson, E., Bougeault, P., and Viterbo, P.: Towards a Kalman Filter based soil moisure analysis system for the operational ECMWF integrated forecst system, Geophys. Res. Lett., 36, L10401, doi:10.1029/2009GL037716, 2009.

Durand, Y., Brun E., Merindol, L., Guyomarc'h, G., Lesaffre, B., and Martin E.: A meteorological estimation of relevant parame- ters for snow models, Ann. Glaciol., 18, 65-71, 1993.

Douville, H., Viterbo, P., Mahfouf, J.-F., and Beeljars, A.: Evaluation of the optimum interpolation and nudging technique for soil analysis using FIFE data, Mon. Weather Rev., 128, 1733-1756, 2000.

Entin, J. K., Robock, A. N., Vinnikov, K. Y., Hollinger, S. E., Liu, S., and Namkhai, A.: Temporal and spatial scales of observed soil moisture variations in the extratropics, J. Geophys. Res., 105(D9), 11865-11877, 2000.

Etchevers, P., Golaz, C., and Habets, F.: Simulation of the water budget and the river flows of the Rhone basin from 1981 to 1994 , J. Hydrol., 244, 60-85, 2001.

FAO: Digital soil map of the world and derived soil properties. Food and Agriculture Organization of the United Nations, Land and Water Digital Media Series, CD-ROM, 2003.

FAO/IIASA/ISRIC/ISSCAS/JRC: Harmonized World Soil Database (version 1.1), FAO, Rome, Italy and IIASA, Laxenburg, Austria, 2009.

Fischer, C., Montmerle, T., Berre, L., Auger, L., and Stefanescu, S. E.: An overview of the variational assimilation in the ALADIN/France numerical weather-prediction system, Q. J. Roy. Meteorol. Soc., 131, 3477-3492, doi:10.1256/qj.05.115, 2006.

Georgakakos, K. P. and Carpenter, M.: Potential value of operationally available and spatially distributed ensemble soil water estimates for agriculture, J. Hydrol., 328, 177-191, 2006.

Giard, D. and Bazile, E.: Implementation of a new assimilation scheme for soil and surface variables in a global NWP model, Mon. Weather Rev., 128, 997-1015, 2000.

Habets, F., Noilhan, J., Golaz, C., Goutorbe, J. P., Lacarre're, P., Leblois, E., Ledoux, E., Martin, E., Ottlé, C., and Vidal-Madjar, D.: The ISBA surface scheme in a macroscale hydrological model applied to the Hapex-Mobilhy area, part 2: simulation of streamflows and annual water budget, J. Hydrol., 217, 97-118, 1999.

Habets, F., Ducrocq, V., and Noilhan, J.: Prévisions hydrologiques et échelles spatiales: 1'exemple des modèles opérationnelles de Météo-France, C. R. Geoscience, 337, 181-192, 2005.

Habets F., Boone, A., Champeaux, J.-L., Etchevers, P., Franchisteguy, L. et al.: The SAFRAN-ISBA-MODCOU 5 hydrometeorological model applied over France, J. Geophys. Res., 113, D06113, doi:10.1029/2007JD008548, 2008.

Kerr, Y., Waldteufel, P., Wigneron, J.-P., Martinuzzi, J.-M., Font, J., and Berger, M.: Soil moisture retrieval from space: the soil moisture and ocean salinity (SMOS) mission, IEEE T. Geosci. Remote, 39, 1729-1736, 2001.

Kerr, Y.: Soil moisture from space: where are we?, Hydrogeol. J., 15(1), 117-120, 2007. Ledoux, E., Girard, G., De Marsily, G., and Deschenes J.: Spatially distributed modelling: conceptual approach, coupling surface water and ground water, in: Unsaturated Flow Hydrologic Modeling: Theory and Practice, NATO ASI Series C, vol. 275, edited by: Morel- Seytoux, H. J., Kluwer Acad., Norwell, Mass., 435-454, 1989.

Lemaître F., Poussie're, J.-C., Kerr, Y., Dejus, M., Durbe, R., de Rosnay, P. et al.: Design and test of the groud based L-band radiometer for Estimating Water In Soils (LEWIS), IEEE T. Geosci. Remote, 42(8), 1666-1676, 2004.

Mahfouf, J.-F.: Analysis of soil moisture from near surface parameters: A feasibility study, J. Appl. Meteorol., 30, 506-526, 1991.

Mahfouf, J.-F., Bergaoui, K., Draper, C., Bouyssel, F., Taillefer, 
F., and Taseva, L.: A comparison of two off-line soil analysis schemes for assimilation of screen level observations, J. Geophys. Res., 114, D08105, doi:10.1029/2008JD011077, 2009.

Naeimi, V., Scipal, K., Bartalis, Z., Hasenauer, S., and Wagner, W.: An improved soil moisture retrieval algorithm for ERS and METOP scatterometer observations, IEEE T. Geosci. Remote, 47(7), 1999-2013, doi:10.1109/TGRS.20082011617, 2009.

Njoku, E. G., Jackson, T. J., Lakshmi, V., Chan, T. K., and Nghiem, S. V.: Soil moisture retrieval from AMSER-E, IEEE T. Geosci. Remote, 41(2), 215-123, 2003.

Noilhan, J. and Planton, S.: A simple parameterisation of land surface processes for meteorological model, Mon. Weather Rev., 117, 356-549, 1989.

Noilhan, J. and Mahfouf, J.-F.: The ISBA land surface parameterisation scheme, Global Planet. Change, 13, 145-149, 1996.

Pellarin, T., Calvet, J.-C., and Wagner, W.: Evaluation of ERS scatterometer soil moisture products over a half-degree region in Southwestern France, Geophys. Res. Lett., 33, L17401, doi:10.1029/2006GL027231, 2006.

Quintana Segui, P., Lemoigne, P., Durand, Y., Martin, E., Habets, F. et al.: Analysis of near surface atmospheric variables: validation of the SAFRAN analysis over France, J. Appl. Meteorol. Clim., 47, 92-107, 2008.

Rüdiger, C., Calvet, J.-C., Gruhier, C., Holmes, T., De Jeu, R., and Wagner, W.: An intercomparison of ERS-Scat and AMSR-E soil moisture observations with model simulations over France, J. Hydrometeorol., 10(2), 431-447, doi:10.1175/2008JHM997.1., 2009.

Schmugge, T. J.: Remote sensing of soil moisture: recent advances, IEEE T. Geosci. Remote, GE21, 145-146, 1983.

Scipal, K., Drusch, M., and Wagner, W.: Assimilation of a ERS scatterometer derived soil moisture index in the ECMWF numerical weather prediction system, Adv. Water Res., 31, 1101-1112, doi:10.1016/j.advwatres.2008.04.013, 2008.

Ulaby, F. T., Moore, R. K., and Fung, A. K.: Physical mechanisms and empirical models for scattering and emission, in: Microwave Remote Sensing: Active and Passive, vol. II, Artech House, Boston, MA, 816-921, 1982.
Vachaud, G., Passerat de Silans, A., Balabanis, P., and Vauclin, M.: Temporal stability of spatially measured soil water probability density function, Soil Sci. Soc. Am. J., 49, 822-828, 1985.

van den Hurk, B., Ettema, J., and Viterbo, P.: Analysis soil moistures changes in Europe during a single growing season in a new ECMWF soil moisture assimilation system, J. Hydrometeorol., 9, 116-131, 2008.

Voirin-Morel, S.: Modélisation distribuées des flux d'eau et d' énergie et des débits à l' échelle régionale du bassin Adour Garonne, Ph.D. thesis, Univ. Paul Sabatier-Toulouse III, Toulouse, 292 pp., France.

Wagner, W., Lemoine, G., and Rott, H.: A method for estimating soil moisture from ERS scatterometer and soil data, Remote Sens. Environ., 70, 191-207, 1999a.

Wagner, W., Lemoine, G., Borgeaud, M., and Rott, H.: A study of vegetation cover effects on ERS scatterometer data, Geosci. Remote Sens., 37(2), 938-948, 1999b.

Wagner, W., Naeimi, V., Scipal, K., de Jeu, R., and MartinezFern'andez, J.: Soil moisture from operational meteorological satellites, Hydrogeol. J., 15, 121-131, 2007a.

Wagner, W., Blöschl, G., Pampaloni, P., Calvet, J.-C., Bizzarri, B., Wigneron, J.-P., and Kerr, Y.: Operational readiness of microwave remote sensing of soil moisture for hydrologic applications, Nord. Hydrol., 38(1), 1-20, doi:10.2166/nh2007.029, $2007 b$.

Wagner, W., Pathe, C., Boubkova, M., Sabel, D., Bartsch, A. et al: Temporal stability of soil moisture and radar backscatter observed by the advanced synthetic aperture radar (ASAR), Sensor, 8, 1174-1197, 2008.

Walker, J. P. and Houser, P. R.: Hydrologic data assimilation, in: Advances in Water Science Methodologies, edited by: Aswathanarayana, A., and Balkema, A. A., The Netherlands, 230 pp., 2005.

White, I., Knight, J. H., Zegelin, S. J., and Topp, G. C.: Comments on "Considerations on the use of time-domain reflectometry (TDR) for measuring soil water content", edited by: Whalley, W. R., Response, Eur. J. Soil Sci., 45(4), 503-510, 1994. 